\title{
The supervision of registered social workers in Aotearoa New Zealand: A national survey
}

\author{
Kieran B. O’Donoghue, Massey University, New Zealand
}

\begin{abstract}
INTRODUCTION: Registered social workers in Aotearoa New Zealand are expected to participate in supervision in accordance with the Social Workers Registration Board's policies. This article reports baseline findings on the supervision of registered social workers, comparing their supervision with the Board's policy and guidelines.

METHODS: A postal survey of 278 registered social workers was conducted to establish a baseline regarding their supervision. IBM SPSS 24 was used to analyse the data. Descriptive analysis, one-way ANOVA and post hoc tests were applied to explore variances in means for the independent variables of registration type, gender, age, ethnic identity, sexual orientation, recognised qualifications, and experience as social worker across 11 scales concerning the respondents' supervision.
\end{abstract}

FINDINGS: The findings report demographic information about the supervisees as well as a description of the supervision they participated in. This includes detail about various aspects of supervision, including forms, overall emphasis, logistics, types of contact, climate, methods and processes, experiences of their supervisor's approaches and models, session processes and content and their overall satisfaction and evaluation.

CONCLUSIONS: While most registered social workers' supervision is in accordance with the Board's expectations and Code of Conduct, further work is needed to ensure all registered social workers participate in appropriate supervision that meets these expectations. Concerns are raised about the cultural responsiveness of supervision in relation to supervisees and clients. Suggestions are made concerning further research in relation to the influence of gender, culture, sexual orientation, experience, qualifications, and registration status within supervision.

KEYWORDS: supervision, social work, registration

AOTEAROA

NEW ZEALAND SOCIAL WORK 31(3), 58-77.

CORRESPONDENCE TO: Kieran B. O'Donoghue K.B.ODonoghue@ massey.ac.nz
Social work supervision is a professional process that social workers engage in to improve their practice with clients and their professional development as practitioners (O'Donoghue, 2010). The first national survey of the supervision of social workers was conducted in 2004 (O'Donoghue, 2008, 2010; O’Donoghue, Munford, \& Trlin, 2005,
2006). This survey occurred prior to the introduction of social worker registration in December 2004 (O'Donoghue, 2013). The establishment of registration by the Social Workers Registration Board (SWRB) has influenced the supervision of social workers by: a) requiring 2000 hours of supervised practice post-qualifying for 
provisionally registered social workers to progress to full registration; $b$ ) registered social workers having to declare that they are participating in supervision and be able to provide a supervision contract if requested when applying for an annual practising certificate or renewing their competency; and c) requiring registered social workers to access appropriate supervision at least monthly (O'Donoghue, 2010; SWRB, 2015a). The Board's Code of Conduct includes expectations that supervisors will ensure their supervision is culturally relevant if the supervisee is Māori and culturally relevant, safe, and responsive for Māori clients (SWRB, 2016). Other expectations in the Code related to supervision include: registered social workers seeking supervision and guidance in regard to staying within scope; actively participating in supervision and critically reflecting on their practice (SWRB, 2016). The study reported in this article aims to establish a baseline in regard to the supervision of registered social workers and to compare and contrast their supervision with SWRB policy and guidelines. The importance of a baseline for the profession is that it enables the possibility for a future comparison of the state of supervision through replicating the survey. Internationally, only one national survey of social workers supervision has been replicated and that was Kadushin's survey of members of National Association of Social Workers (NASW) in 1973 and 1989 (Kadushin, 1974, 1993).

\section{Instrument design and data collection}

The survey questionnaire was an updated version of an instrument used in 2004 (O'Donoghue, 2010; O'Donoghue et al., 2005). The updates included: changing the gender options from binary to multichoice; the addition of sexual orientation as a variable; an updated list of supervision approaches; and the addition of an overall satisfaction scale alongside overall evaluation. The questionnaire consisted of multi-choice questions which sought information on the respondents' background and 5-point semantic differential and likert type scales which measured: the participation in forms of supervision; the emphasis of supervision; the experience of types of supervision contact; the supervision climate; focus, methods and processes; aspects of supervision sessions; approach used; the content of sessions related to practice and organisational matters, and overall satisfaction and evaluation. The internal reliability of the scales in the 2014 questionaire were tested using Cronbach's Alpha coefficient, with 10 of the 11 scales (see Table 1) showing scores that indicated an adequate level of internal consistency (i.e., >0.5) with seven of these achieving a level greater than 0.7 which is generally accepted as a good indication of internal reliability (Helms, Henze, Sass, \& Mifsud, 2006). The participation in forms of supervision scale whist obtaining a low internal reliability score did not have any

Table 1. Internal Reliability

\begin{tabular}{|l|l|}
\hline Scale & $\begin{array}{c}\text { Cronbach's } \\
\text { Alpha } \\
\text { Coefficient }\end{array}$ \\
\hline Participation in forms of supervision & .425 \\
\hline The emphasis of supervision & .612 \\
\hline $\begin{array}{l}\text { The experience of types of } \\
\text { supervision contact }\end{array}$ & .522 \\
\hline $\begin{array}{l}\text { Statements concerning the } \\
\text { supervision climate }\end{array}$ & $.934^{*}$ \\
\hline $\begin{array}{l}\text { Focus of supervision } \\
\text { Methods and processes }\end{array}$ & .690 \\
\hline Aspects of supervision sessions & $.893^{*}$ \\
\hline \begin{tabular}{l} 
Model or approach used \\
\hline $\begin{array}{l}\text { Content of sessions } \\
\text { (supervisee's practice) }\end{array}$
\end{tabular} & $.862^{*}$ \\
\hline $\begin{array}{l}\text { Content of sessions } \\
\text { (organisational matters) }\end{array}$ & $.883^{*}$ \\
\hline $\begin{array}{l}\text { Overall satisfaction and evaluation } \\
\text { *Indicates internal reliability }\end{array}$ & $.770^{*}$ \\
\hline $.797^{*}$
\end{tabular}


implications with regard to use of the data collected for this question, because it corresponds to Schmitt's (1996, p. 352) criterion of a measure that "has other desirable properties, such as meaningful content coverage...", with the content in this case being participation in a range of forms of supervision across a 12-month period.

Arguably, the questionnaire had content, criterion and face validity, because it addressed the content and criteria pertaining to social work supervision and its constitutive elements as described in the supervision literature (Kadushin \& Harkness, 2014; O'Donoghue \& Tsui, 2015). It also built on the constructs from a previous instrument (De Vaus, 2014). The sampling and data-collection procedure involved selecting a sample of 708 registered social workers using a set of randomly generated numbers from the 4388 registered social workers who held annual practising certificates on the publicly available register in 2014. The questionnaire was posted to the participants in December 2014 and followed up with a reminder in January 2015 with data collection finishing in February 2015. Twenty questionnaires were returned unclaimed. From the 688 questionnaires deemed to have been received, 278 questionnaires were returned giving a response rate of $40.4 \%$. The overall sampling error was calculated to be $5.7 \%$ at the $95 \%$ confidence level, which is within the parameters of $4 \%$ and $8 \%$ at the $95 \%$ confidence level, which is deemed acceptable (Field, 2013). The completed questionnaires were checked, coded and data was directly entered into IBM SPSS 24 (http: / / www.ibmspss.com) for analysis. Missing data were addressed by leaving the cells in IBM SPSS 24 blank and by reporting the number of respondents throughout the article (Pallant, 2013).

\section{Data analysis}

The analysis involved descriptive statistics in the form of count, percentage and means. Following the descriptive analysis, a one-way
ANOVA was applied to compare the mean results from the scales with the independent variables derived from the respondents' characteristics and where significant differences were identified, Tamhane T2 post hoc tests were applied to measure the differences and to identify which groups had differences that were statistically significant. Tamhane $\mathrm{T} 2$ tests are used when the variances are unequal and samples differed, which was the case with the respondents' demographic characteristics. The eta squared coefficient $(\eta 2)$ was used to measure the effect size. The effect is deemed small at 0.01, medium at 0.06 and large at 0.14 (Pallant, 2013, p. 264). The alpha level was set at 0.05 .

The study was approved by the Massey University Human Ethics Committee. The main ethical question explored the rationale for gathering sexual orientation data. The ethics committee was advised that Watkins (2011, p. 63) noted that "with regard to sexual orientation and supervision, there continues to be a noticeable gap in the empirical literature." It was also explained to the committee that, in a previous study, several supervisees and a supervisor identified that differences in sexual orientation affected their supervision relationships (O'Donoghue, 2010). The limitations of the survey are those that apply to any survey and concern the reliance on the respondents' reports, social desirability bias, missing data bias, and the small sample size of some respondent characteristic groups (De Vaus, 2014).

\section{Respondents' personal and professional characteristics}

The respondents' personal characteristics are detailed in Table 2. It is difficult to ascertain how representative their characteristics are of the wider social worker population due to a lack of reliable workforce data at the time of the survey. The comparisons made with 2013 New Zealand Census Social Work sub-group have limitations. For example, the comparison for gender suggests females were over-represented in the survey sample 
and males were underrepresented. Another limitation is that the census question was binary and did not include a specific response for people who are gender diverse (Statistics New Zealand, 2017a).

The comparison for age bands is also challenging because the grouping between the survey and the census differ. That said, when the survey age groups results are combined with $12.4 \%(n=31)$ of 274 respondents under 40 years, nearly twothirds $65.7 \%(n=180)$ were between 40 and 59 years of age, just over one-fifth $21.9 \%$ $(n=60)$ were between aged 60 and 69 , there seems to be a degree of alignment with the census. For ethnicity, the main differences between the survey and the census concern those who identify as Indian and Other. In the survey sample 'other' consisted of 14 (5\%) of British origins, among this group, five were English, one was Scottish and the other Welsh. The remaining 8.7\% included six who were European, (i.e., Dutch, Swiss, German, French and a combination of identities), five Australians, four Filipinos and four from Africa, the rest consisted of individuals of North American, Japanese, Chilean, Jewish, Hawaiian/German, and Fijian Indian heritage. An alternative comparison to census was the SWRB 2014/15 annual report, which showed both

Table 2. Personal Characteristics

\begin{tabular}{|c|c|c|c|c|c|}
\hline \multirow{2}{*}{\multicolumn{2}{|c|}{ Personal Characteristics }} & \multicolumn{2}{|c|}{ Respondents } & \multicolumn{2}{|c|}{2013 census Social Work sub-group } \\
\hline & & $\mathbf{N}$ & $\%$ & $\mathbf{N}$ & $\%$ \\
\hline \multirow[t]{3}{*}{ Gender } & Female & 231 & 83.1 & 13464 & 73.5 \\
\hline & Male & 41 & 14.7 & 4869 & 26.5 \\
\hline & Diverse & 6 & 2.2 & & \\
\hline \multicolumn{2}{|l|}{ Total } & 278 & 100 & & \\
\hline \multirow[t]{5}{*}{ Age } & $20-29$ & 3 & 1.1 & $(15-24 y r s) 1191$ & 6.4 \\
\hline & $30-39$ & 31 & 11.3 & (25-44yrs) 6708 & 36.6 \\
\hline & $40-49$ & 83 & 30.3 & $(45-64 y r s) 9363$ & 51.1 \\
\hline & $50-59$ & 97 & 35.4 & (65yrs \& over) & \\
\hline & $60-69$ & 60 & 21.9 & 1074 & 5.9 \\
\hline Total & & 274 & 100 & & \\
\hline \multirow[t]{5}{*}{ Ethnicity } & Māori & 53 & 19.1 & 2,700 & 14.7 \\
\hline & NZ European/ Pākehā & 155 & 55.8 & 10,218 & 55.7 \\
\hline & Pacific Peoples & 20 & 7.2 & 1,494 & 8.2 \\
\hline & Indian & 12 & 4.3 & - & - \\
\hline & Other & 38 & 13.6 & 3,918 * & $21.4^{*}$ \\
\hline Total & & 278 & 100 & & \\
\hline \multirow{3}{*}{$\begin{array}{l}\text { Sexual } \\
\text { Orientation }\end{array}$} & Same-sex & 25 & 9.9 & - & - \\
\hline & Bisexual & 8 & 3.2 & - & - \\
\hline & Heterosexual & 219 & 86.9 & - & - \\
\hline Total & & 252 & 100 & & \\
\hline
\end{tabular}

${ }^{*}$ People of Indian ethnicity are included in this group. 
similarities and differences between the sample and registered social workers with 20.01\% Māori, 67.05\% European Pākehā, Pacific 5.31\%, Indian 2.4\%, Asian, 2.38\%, African, $1.45 \%$, Middle Eastern $0.26 \%$, Hispanic $0.11 \%$, and Other $1.02 \%$ (SWRB, 2015b). Turning to the sexual orientation data, it is important to note that it is not asked for in the New Zealand Census and that estimates of the prevalence of sexual orientations are unreliable statistically and problematic in terms of definition as well as being a political issue (Henrickson, Neville, Jordan, \& Donaghey, 2007; Statistics New Zealand, 2017b). Despite the limitations outlined above concerning the wider social work workforce data, it is argued that the respondents were reasonably representative sample of social workers in regard to their personal characteristics.
The respondents' professional characteristics are detailed in Table 3. At the time of the survey there were no data available from the SWRB to establish how representative the sample is of the professional characteristics presented below. In regard to recognised qualifications the 'other' group held overseas qualifications. Having outlined the respondents' personal and professional characteristics the focus turns to their experiences and views of their supervision.

\section{Respondents' experiences and views of their supervision}

The results reported concern the respondents' experiences and views as supervisees in regard to the forms of supervision they participated in, the overall emphasis, logistics, types of contact, the

Table 3. Professional Characteristics

\begin{tabular}{|c|c|c|c|}
\hline \multicolumn{2}{|c|}{ Professional Characteristics } & \multicolumn{2}{|c|}{ Respondents } \\
\hline & & \multirow{2}{*}{$\frac{\mathbf{N}}{264}$} & \multirow{2}{*}{$\begin{array}{l}\% \\
95.3\end{array}$} \\
\hline Type of Registration & Full & & \\
\hline & Provisional & 11 & 4 \\
\hline & Temporary & 2 & 0.7 \\
\hline \multicolumn{2}{|l|}{ Total } & 277 & 100 \\
\hline \multirow[t]{7}{*}{ Experience in years } & $1-5$ & 31 & 11.3 \\
\hline & $6-10$ & 49 & 17.9 \\
\hline & $11-15$ & 62 & 22.6 \\
\hline & $16-20$ & 44 & 16.0 \\
\hline & $21-25$ & 38 & 13.9 \\
\hline & $26-30$ & 32 & 11.7 \\
\hline & $>31$ & 18 & 6.6 \\
\hline Total & & 274 & 100 \\
\hline \multirow[t]{6}{*}{ Recognised Qualification } & $\begin{array}{l}\text { Section } 13 \text { (on the basis of prior social } \\
\text { work experience) }\end{array}$ & 7 & 2.5 \\
\hline & Diploma & 71 & 25.7 \\
\hline & Bachelors & 107 & 38.8 \\
\hline & PG Dip & 35 & 12.7 \\
\hline & Masters & 49 & 17.8 \\
\hline & Other & 7 & 2.5 \\
\hline Total & & 276 & 100 \\
\hline
\end{tabular}


supervision climate, focus, methods and processes. The respondents' views and experiences of supervisors' use of ideas from supervision models or approaches, the features and contents of sessions and their overall satisfaction and overall evaluation with their supervision are also presented. As discussed previously, these areas encompass the main areas in the supervision literature and align with the SWRB Policy and Code (Kadushin \& Harkness, 2014; O’Donoghue \& Tsui, 2015; SWRB, 2015a, 2016).

\section{Forms of supervision}

The respondents rated on a 5-point scale (where 1 = none and 5 = high) their level of participation in each of 12 forms of supervision over the last 12 months. The 12 forms encompass the differing ways supervision is construed and practised in Aotearoa New Zealand (O’Donoghue \& Tsui, 2012).
Table 4 details the number of responses, the mean, and the percentage of those participating in each form as well as those who reported high participation. The average range of participation was from 4.05 to 1.72, with the respondents mostly participating in individual, clinical/professional, internal and peer forms of supervision. The 'other' category consisted of a range of comments, which included references to specialist supervision, (e.g., spiritual supervision, or for clients with particular conditions or issues such as personality disorder or alcohol drug addiction, or academic supervision of advanced degree study), or the characteristics of their supervision (e.g., multi-disciplinary team, or with peers either inside or outside the office, or via internet and phone). One-way ANOVA tests were conducted to compare the effect of the independent variables of the respondents' characteristics with the dependent variables of forms of supervision. From these tests,

Table 4. Forms of Supervision

\begin{tabular}{|c|c|c|c|c|}
\hline Form of Supervision & $\mathbf{N}$ & $\begin{array}{c}\text { Supervisee } \\
\text { Mean }\end{array}$ & $\begin{array}{c}\% \text { Supervisee } \\
\text { participation } \\
\text { (i.e., 2-5) }\end{array}$ & $\begin{array}{c}\% \text { Supervisee } \\
\text { high participation } \\
\text { (i.e., 5) }\end{array}$ \\
\hline Individual & 243 & 4.05 & 93.4 & 51.0 \\
\hline Clinical/Professional & 259 & 3.83 & 91.9 & 40.5 \\
\hline Internal & 252 & 3.71 & 86.5 & 40.9 \\
\hline Peer & 248 & 3.32 & 82.3 & 25.4 \\
\hline $\begin{array}{l}\text { Managerial/ } \\
\text { Administrative }\end{array}$ & 233 & 2.79 & 68.2 & 20.6 \\
\hline External & 240 & 2.56 & 46.7 & 28.3 \\
\hline Team & 236 & 2.45 & 59.3 & 10.6 \\
\hline Group & 229 & 2.21 & 50.7 & 8.3 \\
\hline Cultural & 233 & 2.10 & 54.1 & 8.2 \\
\hline $\begin{array}{l}\text { Student or Fieldwork } \\
\text { placement }\end{array}$ & 228 & 2.05 & 41.7 & 10.1 \\
\hline $\begin{array}{l}\text { Cross-disciplinary/ } \\
\text { Interprofessional }\end{array}$ & 224 & 1.72 & 31.2 & 6.7 \\
\hline Other & 17 & 2.59 & 52.9 & 23.5 \\
\hline
\end{tabular}

*Level of participation ranged from 1 (none) to 5 (high) 
significant mean differences were found in relation to gender, ethnicity, experience, and recognised qualification. The gender difference concerned participation in individual supervision $(\mathrm{F}(3,239)=3.918, \mathrm{p}<.01)$, with females $(M=4.15, S D=1.189, n=203)$ having a higher mean than males $(M=3.4, S D=1.397$, $n=35)$. The effect of this difference was small ( $\eta 2=.047)$. It is possible that this difference, given its small effect size, may be derived from the differences in sample sizes between the female and male respondents.

The significant ethnicity differences concerned cultural supervision and group supervision. For cultural supervision $(\mathrm{F}(4,228)=6.088, \mathrm{p}<.001)$, Pacific peoples $(M=3.16, S D=1.642, n=19)$ had a higher mean than New Zealand (NZ) European / Pākehā $(M=1.81, S D=1.072, n=124)$ with the effect size being medium ( $\eta 2=.096)$. A similar difference was found for group supervision $(\mathrm{F}(4,224)=3.575, \mathrm{p}<.01)$ with Pacific peoples $(M=3.21, S D=1.273, n=19)$ having a higher mean than NZ European / Pākehā $(M=1.99, S D=1.311, n=126)$ with a medium effect size $(\eta 2=.06)$. The significant differences between Pacific peoples and NZ European/Pākehā for both forms of supervision are not surprising and reflect the development of models of cultural supervision for Pacific peoples (Autagavaia, 2001; Su'a Hawkins \& Mafile'o, 2004) as well as the development of Pacific social work and social services in Aotearoa New Zealand (Dalhousie, 2010).

The differences regarding experience in social work concerned participation in internal supervision $(\mathrm{F}(6,242)=3.472, \mathrm{p}<.001)$, where respondents with 1-5 years' experience $(M=4.36, S D=.78, n=12)$ had significant higher means for participation in internal supervision than respondents with 16-20 years $(M=3.32, S D=1.572, n=28)$ and $26-30$ years' experience $(M=2.96, S D=1.644, n=$ 19). These differences had a medium effect size ( $\eta 2=.079)$ and indicate that beginning practitioners have, on average, a higher participation in internal supervision than their more experienced colleagues.
The difference pertaining to recognized qualification concerned participation in managerial/administrative supervision $(\mathrm{F}(5,226)=3.051, \mathrm{p}<.01)$ with those who were registered under section 13 of the Social Workers Registration Act (2003) on the basis of prior social work experience $(M=4.57$, $S D=.787, n=6)$, having a higher mean than those with diplomas $(M=2.9, S D=1.524$, $n=66)$, bachelor's degrees $(M=2.64$, $S D=1.502, n=96)$, postgraduate diplomas $(M=3.1, S D=1.729, n=31)$ and master's degrees $(M=2.57, S D=1.417, n=46)$. The effect size of these differences was small $(\eta 2=.049)$ and it may be plausible that this result is due to the small sample size within the section 13 group. Nonetheless, the section 13 group's participation in supervision may warrant further research to ascertain if there are any differences in their participation from those who are formally qualified and had completed supervised placements.

\section{Overall emphasis of supervision}

The respondents rated the overall emphasis of their supervision on a 5-point scale (where $1=$ not at all and 5 = almost always), as it concerned the extent to which their supervision involved the management of their work, their practice with clients, their well-being and development as a worker, and their workplace environment or another aspect which they were to specify. The mean responses ranged from 3.89 to 3.36 , with the management of their work $(M=3.89$, $n=273)$ and practice with clients $(M=3.88$, $n=274$ ), being the most highly rated. The supervisee's well-being and development as a worker $(M=3.65, n=275)$ and their environment of their workplace $(M=3.36$, $n=274)$ with slightly lower means had slightly less overall emphasis with the respondents' supervision. 'Other' $(M=3.57$, $n=30$ ) consisted of items concerned with supervision and management of other colleagues (e.g., supervision of other social workers, management of staff), professional development, cultural matters (e.g., cultural well-being and culture and religion), macro 
issues (policy development and impact on clients) and personal matters (e.g., self-care, and home personal matters). No significant mean differences were identified in regard to the respondent characteristics.

\section{Logistics involved}

Several questions were concerned with the logistics involved in supervision, including the number of supervisors with whom they currently had a supervision relationship, the type of supervision agreements or contracts, the frequency of supervision contact and the average length of supervision sessions. Just under half of 275 respondents $(49.8 \%$, $n=137$ ) had one supervisor, while $49.5 \%$ $(n=136)$ had more than one supervisor among these the largest group was the third of respondents $(33.5 \%, n=92)$ who had two supervisors. Two respondents $(0.7 \%)$ who stated 'other', did not have a supervisor. Both were fully registered. To ascertain the average number of supervisors, the median was calculated and found to be two.

The respondents were asked to indicate the type of agreement or contract they currently had in place. Most respondents $(90 \%$, $n=250)$ had a supervision agreement of some kind. The majority $(73.6 \%, n=204)$ had written agreements, $10.8 \%(n=30)$ had oral agreements. Some respondents who had more than one supervisor indicated that they had more than one kind of agreement with $5.8 \%(n=16)$ having both oral and written agreements and two respondents had either no agreement or a written agreement. Another two respondents reported their agreements as 'other' but did not specify this and $8.3 \%(n=23)$ reported none. The 23 respondents who did not have an agreement were fully registered.

Questions about the average frequency of the respondents' supervision contact revealed that the majority $(56.2 \%, n=155)$ had monthly contact. Over a fifth of respondents $(22.8 \%, n=63)$ had fortnightly supervision. Overall, $88.4 \%(n=243)$ had supervision at least monthly or more. Other which was $11.6 \%(n=32)$ included a range of experiences related to infrequent supervision which included from six-weekly and bimonthly, to very infrequently and rarely having supervision. Amongst this group of 32 respondents, all but one were fully registered, with one being provisional registered.

For most respondents $(93.2 \%, n=258)$ the average length of their supervision sessions supervision sessions was between 30 and 89 minutes. Of these $49.8 \%(n=138)$ were between 30 and 59 minutes and $43 \%(n=119)$ were between 60 and 89 minutes, with one other who noted that length within this period depended on the agenda. Among the remaining $7.2 \%(n=20), 5.4 \%(n=15)$ had sessions that were between 90 and 120 minutes, $1.1 \%(n=3)$ had sessions that were between 0 and 30 minutes in length.

\section{Types of supervision contact}

The respondents indicated on a 5-point scale (where $1=$ not at all and $5=$ almost always) their experience of a range of types of supervision contact. The means ranged from 3.68 for checking in concerning work plans and activity to 1.96 for formal group sessions (see Table 5). There were significant mean differences found in regard to ethnic groups and in regard to sexual orientation. The ethnic identity differences were for observation $(\mathrm{F}(4,260)=4.879, \mathrm{p}=.001)$ and formal group sessions $(\mathrm{F}(4,260)=6.252$, $\mathrm{p}<.001)$ in both cases Māori had a higher mean $(M=2.46, S D=1.358, n=50$; $M=2.38, S D=1.398, n=50)$ than NZ European / Pākehā $(M=1.82, S D=1.141$, $n=148 ; M=1.7, S D=1.186, n=148)$.

The differences were medium for both observation and formal group sessions with the effect sizes being, $\eta 2=.07$ and $\eta 2=.088$ respectively. This result suggests that Māori respondents are observed more and participate in more formal group supervision sessions than NZ European/Pākehā and appears to be an area for further research regarding why this is so. The significant mean difference related to sexual orientation involved the item checking in concerning 


\section{QUANTITATIVE RESEARCH}

Table 5. Types of Supervision Contact: Frequency of Experience*

\begin{tabular}{|l|r|r|}
\hline Type of supervision contact & $\begin{array}{c}\text { Supervisee } \\
\text { Mean } \\
\text { N }\end{array}$ & $\begin{array}{c}\text { Supervisee } \\
\text { Std. Deviation }\end{array}$ \\
\hline Checking in concerning work plans and & 3.68 & 1.088 \\
\hline activity & 272 & 1.111 \\
\hline Case consultations & 3.67 & 1.291 \\
\hline Formal individual meetings and sessions & 272 & 1.288 \\
\hline Ad hoc informal open door consultations & 270 & 1.175 \\
\hline Reviews/debriefings of specific work or & 3.55 & 1.308 \\
\hline situations & 266 & 1.26 \\
\hline Co-working & 265 & 1.342 \\
\hline Formal team sessions & 2.59 & \\
\hline Observations (either live or recorded) & 269 & 1.292 \\
\hline Formal group sessions & 2.14 & \\
\hline Other & 264 & 1.311 \\
\hline
\end{tabular}

*Frequency ranged from 1 (not at all) to 5 (almost always).

Table 6. Supervision Climate Statements: Level of Agreement*

\begin{tabular}{|c|c|c|c|}
\hline Climate Statements & $\mathbf{N}$ & Mean & $\begin{array}{l}\text { Std. } \\
\text { Deviation }\end{array}$ \\
\hline $\begin{array}{l}\text { I can safely discuss ethical issues in } \\
\text { supervision }\end{array}$ & 276 & 4.26 & 1.071 \\
\hline My supervision is always open and honest & 277 & 4.16 & 1.072 \\
\hline The power dynamics are well managed & 277 & 4.14 & 1.157 \\
\hline $\begin{array}{l}\text { The relationship with my supervisor is } \\
\text { constructive }\end{array}$ & 276 & 4.10 & 1.087 \\
\hline I trust my supervisor & 278 & 4.08 & 1.164 \\
\hline I can safely share my emotions in supervision & 277 & 3.96 & 1.245 \\
\hline $\begin{array}{l}\text { My supervisor has more expertise in } \\
\text { supervision than me }\end{array}$ & 275 & 3.78 & 1.347 \\
\hline $\begin{array}{l}\text { My supervisor has more expertise in practice } \\
\text { than me }\end{array}$ & 277 & 3.62 & 1.363 \\
\hline I have a choice of supervisor & 276 & 3.04 & 1.705 \\
\hline
\end{tabular}

*Level of agreement ranged from 1 (strongly disagree) to 5 (strongly agree). work plans and activity $(\mathrm{F}(2,244)=4.200$, $\mathrm{p}=.016)$ with participants who identified as heterosexual $(M=3.76, S D=1.1, n=215)$ having a significantly higher mean than those who identified as same-sex $(M=3.08$, $S D=1.139, n=24)$. The differences in the mean scores was small $(\eta 2=.033)$. This appears to indicate that checking in occurs, on average, more frequently amongst heterosexual respondents than their samesex attracted colleagues. This result needs to be considered with caution due to the large differences in sample sizes between the two groups. Nonetheless, it does raise a question for further research regarding the influence sexual orientation differences have in supervision.

\section{Views concerning supervision climate}

The respondents rated their level of agreement with nine statements concerning their supervision climate. The climate statements were concerned with the supervisees' views regarding how permissive and supportive their supervision was relative to safety, trust, choice, and relational and power dynamics. The results detailed in Table 6 indicate that, on average, supervision was viewed as being positive, constructive and safe.

There were significant mean differences according to experience and type of registration. The differences for experience concerned supervisory expertise in both practice and supervision. For expertise in practice $(\mathrm{F}(6,266)=7.951, \mathrm{p}<.001)$ those with $1-5$ years' experience $(M=4.58, S D=.72$, $n=31$ ) had higher means than all other groups except $6-10$ years (i.e., $11-15(M=3.69$, $S D=1.385, n=61), 16-20(M=3.32$, $S D=1.427, n=44), 21-25(M=3.26$, $S D=1.389, n=38), 26-30(M=2.94, S D=$ $1.216, n=32)$ and $>31$ years $(M=3.06, S D=$ $1.589, n=18)$. The differences in the mean scores was large $(\eta 2=.152)$. The results for expertise in supervision $(F(6,265)=6.912$, $\mathrm{p}<.001)$ were similar with $1-5$ years $(M=4.65, S D=.839, n=31)$ having significantly higher means than all other 
groups (i.e., $6-10(M=4.3, S D=1.01, n=49)$, $11-15(M=3.89, S D=1.17, n=61), 16-20$

$(M=3.26, S D=1.399, n=43), 21-25$

$(M=3.66, S D=1.438, n=38), 26-30$

$(M=3.25, S D=1.437, n=32),>31$ years

$(M=3.17, S D=1.543, n=18))$. The

differences in the mean scores was medium $(\eta 2=.135)$. The mean differences reveal that those with less than five years' experience are more likely, on average, to acknowledge their supervisors' expertise both in practice and supervision than those with greater experience. The mean differences for type of registration concerned having a choice of supervisor and expertise in supervision. For choice of supervisor $(\mathrm{F}(2,272)=4.058$, $\mathrm{p}=.018)$, those with full registration $(M=3.09, S D=1.711, n=262)$ had a higher mean than those who were provisionally $(M=1.91, S D=.944, n=11)$ and temporarily registered $(M=1, S D=0, n=2)$. The effect of this difference was small $(\eta 2=.029)$. For expertise in supervision $(\mathrm{F}(2,271)=3.546$, $\mathrm{p}=.03$ ) those with provisional registration
$(M=4.82, S D=.405, n=11)$ had a higher mean than those with full registration $(M=3.73, S D=1.36, n=261)$. The effect of this difference was also small ( $\eta 2=.026)$.

These differences which show that provisionally registered social workers have less choice of supervisor and perceive their supervisors have more expertise in supervision than them, were expected. That said, this finding ought to be viewed with caution due to small effect size and the small sample of those who were provisionally and temporarily registered-further research in relation to the differences between these groups experiences is advisable.

\section{Supervision focus, methods and processes}

Turning to the focus of supervision (Table 7), it is evident that the primary focus was safe and ethical practice and that the area focused on the least was the supervisee's learning and development.

Table 7. Focus of Supervision: Level of Agreement*

\begin{tabular}{|l|l|c|c|}
\hline Statement: We focus on & N & Mean & Std. Deviation \\
\hline ... safe and ethical practice & 274 & 4.04 & .977 \\
\hline ...client's issues & 274 & 3.94 & .983 \\
\hline ..the supervisee's needs & 276 & 3.78 & 1.063 \\
\hline ... agency requirements & 276 & 3.73 & 1.010 \\
\hline ...the supervisee's learning and development & 277 & 3.61 & 1.083 \\
\hline
\end{tabular}

*Level of agreement measured as for Table 4 above.

Table 8. Supervision Methods and Processes: Level of Agreement*

\begin{tabular}{|l|l|l|r|}
\hline Statement & N & Mean & Std. Deviation \\
\hline Our supervision is anti-oppressive & 274 & 3.91 & 1.070 \\
\hline Our supervision is strength-based & 276 & 3.89 & 1.065 \\
\hline Our supervision is outcome focused & 275 & 3.77 & .983 \\
\hline Our supervision uses a problem solving process & 275 & 3.76 & 2.578 \\
\hline In supervision we have a shared agenda & 276 & 3.75 & 1.068 \\
\hline Our supervision is task focused & 275 & 3.72 & .966 \\
\hline In supervision we reflect on the client-worker interactions & 273 & 3.62 & 1.088 \\
\hline In supervision we link theory and practice & 274 & 3.17 & 1.218 \\
\hline
\end{tabular}

*Level of agreement measured as for Table 4 above. 
Moving on to the methods and processes occurring in supervision (Table 8), the means across the eight statements ranged from 3.91 for our supervision is that anti-oppressive to 3.17 for the statement concerned with linking theory and practice. There were significant differences for ethnic groups and recognised qualification. The differences between ethnic groups were in relation to the statements concerning a supervision being task focused $(\mathrm{F}(4,270)=3.120, \mathrm{p}=.016)$ and having a shared agenda $(F(4,271)=3.174$, $\mathrm{p}=.014)$. For supervision being task focused, Pacific people $(M=4.2, S D=.768, n=20)$ had a higher mean than NZ European/ Pākehā $(M=3.59, S D=.935, n=153)$. The effect of this difference was small $(\eta 2=.044)$. The differences pertaining having a shared agenda were that 'other' ethnic groups $(M=4.21, S D=.834, n=38)$ had a higher mean New Zealand European/Pākehā $(M=3.63, S D=1.08, n=153)$. The differences were also small $(\eta 2=.045)$. These differences need to be viewed with caution due to the small effect sizes and the differences in sample size between groups. Nonetheless, the results do raise the questions for further research regarding ethnic differences in the methods and processes of supervision.

The significant difference between recognised qualification groups $(F(5,269)=2.447$, $\mathrm{p}=.034$ ) also concern having a shared agenda. In this case that those with Section 13 $(M=4.86, S D=.378, n=7)$ had a higher mean than those who had a diploma $(M=3.54$, $S D=1.205, n=71)$, bachelors $(M=3.83$, $S D=.941, n=106)$, postgraduate diploma $(M=3.83, S D=.923, n=35)$ and masters $(M=3.69, S D=1.122, n=49)$ qualifications. The differences in the mean scores was small $(\eta 2=.043)$. As indicated previously, this result needs to be considered with caution due to the small effect size and the small sample size of section 13 respondents.

\section{Use of ideas from supervision approaches and models}

The respondents rated on a 5-point scale (where $1=$ not at all and $5=$ almost always) their supervisor's use of aspects or ideas from a range of supervision models / approaches. The results are detailed in Table 9. The means

Table 9. Use* of Aspects/ideas from Supervision Approaches and Models

\begin{tabular}{|l|l|c|c|c|}
\hline Approaches/Models & N & $\begin{array}{c}\text { Supervisee } \\
\text { Mean }\end{array}$ & $\begin{array}{c}\text { \% Supervisee } \\
\text { Used to some extent } \\
\text { (i.e. 2-5) }\end{array}$ & $\begin{array}{c}\text { \% Supervisee } \\
\text { A/A } \\
\text { (i.e. 5) }\end{array}$ \\
\hline Strength-based & 268 & 3.97 & 95.9 & 35.8 \\
\hline Solution-Focused & 271 & 3.92 & 97.4 & 31.0 \\
\hline Reflective & 271 & 3.90 & 95.9 & 36.2 \\
\hline Task-Centred & 270 & 3.80 & 96.3 & 27.4 \\
\hline Adult learning & 262 & 3.24 & 86.6 & 19.8 \\
\hline Eclectic & 260 & 3.22 & 83.8 & 15.4 \\
\hline Narrative & 262 & 3.05 & 82.8 & 15.3 \\
\hline Cultural & 264 & 2.55 & 73.5 & 11 \\
\hline Feminist & 258 & 2.29 & 64.3 & 6.2 \\
\hline Kaupapa Māori & 262 & 2.12 & 57.3 & 5.7 \\
\hline Pasifika-based & 258 & 1.53 & 33.3 & 2.3 \\
\hline Other & 19 & 3.11 & 68.7 & 21.1 \\
\hline
\end{tabular}

* Use ranged from 1 (not at all) to 5 (almost always). 
ranged from 3.97 for 'Strength-based' to 1.53 for 'Pasifika-based'. There were very small differences in mean between the four most common approaches (i.e., strength-based, solution focused, reflective and task-centred). Apart from reflective, the other three most commonly experienced approaches were drawn from social work practice models. The items specified under 'other' included several practice approaches, namely, Dialectical behaviour Therapy, Cognitive Behavioural Therapy/mindfulness, Personcentred, Ngā Takepu, Analytical, Existential, Systems focused (Family Therapy) and medical models.

There were significant mean differences for ethnicity. These differences concerned the use of Kaupapa Māori and Pasifika approaches to supervision. The differences in the use of Kaupapa Māori $(\mathrm{F}(4,257)=6.074$, $\mathrm{p}<.001)$ were that Māori $(M=2.65$,

$S D=1.508, n=51)$ had a higher mean than NZ European/ Pākehā $(M=1.84, S D=1.01$, $n=146)$. This difference which had a

medium effect size $(\eta 2=.086)$ was expected and mirrored the result from the 2004 survey (O'Donoghue, 2010). The differences in the use of Pasifika-based approaches $(\mathrm{F}(4,253)=$ 11.384, $\mathrm{p}<.001)$ were that Pacific peoples $(M=2.74, S D=1.522, n=19)$ had higher a mean than both Māori $(M=1.33, S D=.689$, $n=49)$ and NZ European / Pākehā $(M=1.41$, $S D=.742, n=144)$. These differences had a large effect size $(\eta 2=.153)$. Overall, these differences suggest that the Māori and Pacific supervisees, on average, had more experience of their respective culturally relevant approaches or models than NZ European/Pākehā, which is to be expected.

\section{Features and content of supervision sessions}

Using a 5-point scale (where $1=$ not at all and 5 = almost always), the respondents indicated the extent to which a range of features (Table 10) occurred in their supervision sessions.

The means ranged from 4.07 for discussion to 1.41 for karakia (spiritual incantation or prayer). Most of the means were three or higher with only evaluation and karakia being the only aspects with means below three. There were significant differences

Table 10. Occurrence* of Aspects of Sessions

\begin{tabular}{|l|c|c|c|}
\hline \multicolumn{1}{|c|}{ Aspect of sessions } & N & $\begin{array}{c}\text { Supervisee } \\
\text { Mean }\end{array}$ & $\begin{array}{c}\text { Supervisee } \\
\text { Std. Deviation }\end{array}$ \\
\hline Discussion of item(s) & 275 & 4.07 & .974 \\
\hline Action Planning & 275 & 3.86 & 1.009 \\
\hline Decision-making & 272 & 3.79 & .954 \\
\hline Checking- in & 274 & 3.71 & 1.156 \\
\hline Preparation & 270 & 3.59 & 1.110 \\
\hline Summarisation and review & 274 & 3.48 & 1.244 \\
\hline Agenda setting & 273 & 3.42 & 1.186 \\
\hline Prioritisation of items & 273 & 3.37 & 1.266 \\
\hline Closure & 274 & 3.25 & 1.416 \\
\hline Evaluation & 273 & 2.99 & 1.321 \\
\hline Karakia (Spiritual Incantation or prayer) & 263 & 1.41 & 1.011 \\
\hline
\end{tabular}

*Occurrence ranged from 1 (not at all) to 5 (almost always). 
for ethnicity and experience. For ethnicity, the difference concerned the occurrence of karakia $(\mathrm{F}(4,258)=9.492, \mathrm{p}<.001)$ with Māori $(M=2, S D=1.471, n=50)$ having a higher mean than NZ European/ Pākehā $(M=1.2, S D=.708, \mathrm{n}=147)$ Indian $(M=1.08$, $S D=.289, \mathrm{n}=12)$ and 'other' $(M=1.23, S D=.77$, $n=35)$. The effect size was medium $(\eta 2=.128)$. This difference was expected since there was a similar finding concerning of occurrence of karakia the in 2004 survey (O'Donoghue, 2010). The difference related to experience was for prioritisation of items $(\mathrm{F}(6,262)=3.222$, $\mathrm{p}=.005)$ with those with 6-10 years $(M=3.71, S D=1.155, n=49)$ having a higher mean than $16-20$ years $(M=2.79, S D=1.264$, $n=43$ ). The effect size of these differences was medium ( $\eta 2=.069)$. This was an unexpected finding which raises question for further research regarding whether there are differences between supervisees' experience and the occurrence of prioritising items in their sessions.
The respondents indicated (on a 5-point scale, where $1=$ not at all and $5=$ almost always) how frequently a range of items were discussed in their supervision sessions (Table 11). The means for ranged from 4.26 for complex and challenging cases to 2.58 for the supervision relationship. The other commonly discussed items which scored 3 or more on the scale related to the supervisee's concerns, caseload, workload, ethics, successes, their team, boundaries and stress. The 'other' items specified generally aligned with those listed with a couple of exceptions being 'depends', 'annual leave' and 'my role as a supervisor'. The only significant mean difference involved sexual orientation and performance management $(\mathrm{F}(2,247)=3.854, \mathrm{p}=.022)$ which was higher mean among bisexual respondents $(M=3.75$, $S D=.886, n=8)$ than for same-sex $(M=2.44$, $S D=.1 .193, n=25)$ and heterosexual $(M=2.74$, $S D=1.167, n=217)$. The effect of these differences was small $(\eta 2=.03)$. This finding

Table 11. Items that are Commonly Discussed in Supervision Sessions

\begin{tabular}{|l|l|l|l|}
\hline Items & N & Mean & Std. Deviation \\
\hline Complex or challenging cases & 274 & 4.26 & .939 \\
\hline Supervisee's concern or matters & 273 & 3.83 & 1.075 \\
\hline Caseload review & 274 & 3.64 & 1.200 \\
\hline Workload & 275 & 3.63 & 1.061 \\
\hline Professional Development & 275 & 3.55 & 1.124 \\
\hline Ethical issues & 273 & 3.50 & 1.088 \\
\hline Success Stories & 274 & 3.47 & 1.110 \\
\hline Team issues & 275 & 3.32 & 1.071 \\
\hline Boundaries & 266 & 3.15 & 1.062 \\
\hline Stress & 273 & 3.14 & 1.141 \\
\hline Problems with Management & 274 & 2.93 & 1.162 \\
\hline Problems with the Organisation & 274 & 2.93 & 1.111 \\
\hline Supervisor's concerns or matters & 274 & 2.89 & 1.116 \\
\hline Personal issues & 273 & 2.89 & 1.175 \\
\hline Problems with colleagues & 272 & 2.88 & 1.117 \\
\hline Cultural matters & 270 & 2.79 & 1.224 \\
\hline Performance Management & 274 & 2.75 & 1.189 \\
\hline The supervision relationship & 270 & 2.58 & 1.228 \\
\hline Other & 19 & 3.42 & 1.610 \\
\hline Frequency ranged from 1 & & \\
\hline
\end{tabular}

*Frequency ranged from 1 (not at all) to 5 (almost always). 
was surprising and is to be considered with caution due to the small effect size and small sample of respondents $(n=8)$ who identified as bisexual.

\section{Overall satisfaction and overall evaluation}

The respondents rated on a scale (where $1=$ not at all and $5=$ completely satisfied) the number that best described their overall satisfaction as supervisees. The mean from 278 respondents was $3.73(S D=1.006)$. Over two-thirds $(66.9 \%)$ were very satisfied or completely satisfied (rating 4 and 5 on the scale) with their supervision as a supervisee. When the results for 1 and 2 on the scale were combined $12.2 \%$ were not at all satisfied and less than satisfied. There were $20.9 \%$ who were satisfied or rated it as 3 on the scale. The respondents also rated their overall evaluation of the supervision they participated in as supervisees on a 5-point scale (where $1=$ poor and $5=$ excellent). Just under two-thirds of 275 respondents $(64.4 \%)$ evaluated their supervision as excellent or close to excellent. Those who evaluated their supervision either as poor or close to poor (i.e., 1 and 2 on the scale) were $12.4 \%$. Whereas $23.3 \%$ rated their supervision as good or 3 on the scale. The mean of 3.7 $(S D=.999)$ is close to very good, but lower than the mean of 4.065 from the 2004 survey. From this previous survey, the percentage of those who were poor or close to poor was $4.5 \%$ and those who were excellent or close to excellent was 74.6\% (O'Donoghue, 2010). The difference between the two survey results are that those who rated supervision as poor, or close to poor, were higher in the current survey by $7.9 \%$, whereas those who rated it as excellent, or close to excellent, were lower by $10.2 \%$. In other words, in this survey there are more who reported poor supervision and less who rate excellent supervision.

The reasons for these differences may be due to differences between the samples of ANZASW members and Registered Social Workers. Alternatively, the differences may be due to different expectations of supervision by the present-day respondents in comparison to those who responded in the previous survey.

\section{Summary and discussion}

The baseline established in regard to registered social workers supervision from the results is that they participated in range of forms of supervision over the 12 months prior to the survey, with individual, clinical/ professional, internal and peer forms of supervision being the most common. The overall emphasis of their supervision was primarily on the management of their work and their practice with clients, with their well-being and development as workers and the environment of their workplace having slightly less overall emphasis. Almost half had one supervisor, while the other half had two or more supervisors. This indicates a splitting of the organisational and professional aspects of supervision amongst their supervisors. Two registered social workers did not have supervisors, and did not comply with the SWRB expectations or the Code of Conduct regarding participating in supervision (SWRB, 2015a, 2016). Most had a supervision agreement, with the majority having written agreements. There were 23 registered social workers without a supervision agreement and 30 who had oral agreements. Arguably, these social workers' ability to comply with any request made by the SWRB for their supervision agreement when renewing their practising certificate or competency is somewhat challenged (SWRB, 2015a). The frequency of registered social workers' supervision was that most had supervision at least monthly or more often. There were however, $32(11.6 \%)$ social workers whose supervision was infrequent and did not meet the SWRB's expectation of accessing supervision at least monthly. One of this group was a provisionally registered social worker and undertaking their 2000 hours of supervised practice. The average length of registered social workers' supervision sessions was between 30 and 89 minutes and the most common types of contact that they were involved concerned checking in on their plans and activity, case consultations, reviews 
of specific situations through formal meetings and ad hoc, open-door consultations.

The climate within which supervision was conducted was safe for supervisees to discuss ethical issues and share emotions, due to open, honest, trusting and constructive relationships, in which the power dynamics were well managed. The focus of supervision was on safe and ethical practice, clients' issues, their own needs, their agency's requirements and learning and development. The methods and processes registered social workers experienced in supervision were anti-oppressive, strength-based, outcome focused, used a problem-solving process, a shared agenda and were task focused. They experienced the linking of theory and practice to a lesser extent than the other methods and processes.

The ideas from supervision models and approaches that registered social workers experienced as used by their supervisors were mainly from practice and supervision models and approaches, namely, strength-based (Thomas \& Davis, 2005), solution focused (Thomas, 2013), reflective (Davys \& Beddoe, 2010), and task-centred (Caspi \& Reid, 2002). It was notable that culturally based (Cultural (Su'a-Hawkins \& Mafile'o, 2004), Kaupapa Māori (Eruera, 2012), Pasifika-based (Autagavaia, 2001) and Feminist (Simmons, 2001) approaches and models were the least experienced by registered social workers. The low-level experience of the culturally based approaches raises questions concerning the extent to which supervision meets the SWRB's expectation that it is culturally responsive and cognisant of the cultural worldview of the supervisees and the clients discussed in supervision (SWRB, 2015a, 2016).

For registered social workers as a group, the items that occurred most often in their sessions were discussion, action planning, decision-making, checking in, preparation, prioritisation and closure. Evaluation within sessions occurred to a lesser extent and this was not surprising as this paralleled the 2004 survey findings (O’Donoghue, 2010).
When analysed by frequency, $84.2 \%$ of 273 registered social workers' evaluations occurred within their sessions to some extent, and, for $39.2 \%$, this occurred a lot or almost always. This finding differed from that of Davys, May, Burns, \& O'Connell (2017) who reported that $27 \%$ of the supervisees in their study reported evaluating on a session-bysession basis. The reasons for this difference may be due to the differences in the samples and how the questions were framed.

The most commonly discussed item in supervision was complex and challenging cases, this was followed by matters pertaining to supervisees, their practice with clients and within their team. Cultural matters, with a mean of 2.79 , was the third lowest and raises questions concerning the low presence of a cultural lens in supervision (Hair \& O'Donoghue, 2009). Overall, the majority of registered social workers were satisfied with their supervision and evaluated it positively. It is nonetheless of concern that just over $12 \%(n=34)$ of these registered social workers were dissatisfied and evaluated their supervision as poor or close to poor. It is also of concern that this percentage is higher than that in the 2004 survey. One possible explanation may be found in the differences in the samples. The results also identified significant mean differences in relation to ethnicity, experience as a social worker, recognised qualification, sexual orientation, type of registration and gender. These differences are summarised in relation to the respective independent variable in Table 12.

It is notable that the largest group of differences concerns ethnicity and to some extent these results reinforce the finding from O'Donoghue (2010) concerning how the indigenous, bicultural and multicultural discourses influence the Aotearoa New Zealand social work supervision context. In addition, they are further evidence of the importance of having culture in the forefront of supervision practice and the need for further work in regard to decolonising supervision (Ruwhiu, 2019; Walsh-Tapiata \& Webster, 2004). 
Table 12. Significant Mean Differences Summary by Variables

\begin{tabular}{|c|c|c|c|c|}
\hline Variables & ANOVA & Mean Differences $p<.05$ & SD & $\begin{array}{l}\text { Effect size } \\
\text { Eta squared }\end{array}$ \\
\hline $\begin{array}{l}\text { Ethnicity } \\
\qquad \quad \text { Cultural supervision }\end{array}$ & $(F(4,228)=6.088, p<.001)$ & $\begin{array}{l}\text { Pacific Peoples } \\
3.16 \\
\text { NZ Euro/Pākehā } \\
1.81\end{array}$ & $\begin{array}{l}\text { Pacific Peoples } \\
1.642 \\
\text { NZ Euro/Pākehā } \\
1.072\end{array}$ & $\begin{array}{l}\text { Medium } \\
.096\end{array}$ \\
\hline - Group supervision & $(F(4,224)=3.575, p<.01)$ & $\begin{array}{l}\text { Pacific peoples } \\
3.21 \\
\text { NZ Euro/Pākehā } \\
1.99\end{array}$ & $\begin{array}{l}\text { Pacific peoples } \\
1.273 \\
\text { NZ Euro/Pākehā } \\
1.311\end{array}$ & $\begin{array}{l}\text { Medium } \\
.06\end{array}$ \\
\hline - Observation & $(F(4,260)=4.879, p=.001)$ & $\begin{array}{l}\text { Māori } \\
2.46 \\
\text { NZ Euro/Pākehā } \\
1.82\end{array}$ & $\begin{array}{l}\text { Māori } \\
1.358 \\
\text { NZ Euro/Pākehā } \\
1.141\end{array}$ & $\begin{array}{l}\text { Medium } \\
.07\end{array}$ \\
\hline - Formal group sessions & $F(4,260)=6.252, p<.001)$ & $\begin{array}{l}\text { Māori } \\
2.38 \\
\text { NZ Euro/Pākehā } \\
1.7\end{array}$ & $\begin{array}{l}\text { Māori } \\
1.398 \\
\text { NZ Euro/Pākehā } \\
1.186\end{array}$ & $\begin{array}{l}\text { Medium } \\
.088\end{array}$ \\
\hline $\begin{array}{l}\text { - Our supervision is task } \\
\text { focused }\end{array}$ & $F(4,270)=3.120, p=.016)$ & $\begin{array}{l}\text { Pacific peoples } \\
4.2 \\
\text { NZ Euro/Pākehā } \\
3.59\end{array}$ & $\begin{array}{l}\text { Pacific peoples } \\
.768 \\
\text { NZ Euro/Pākehā } \\
.935\end{array}$ & $\begin{array}{l}\text { Small } \\
.044\end{array}$ \\
\hline $\begin{array}{l}\text { - In supervision we have } \\
\text { a shared agenda }\end{array}$ & $(F(4,271)=3.174, p=.014)$ & $\begin{array}{l}\text { Other ethnic groups } \\
4.21 \\
\text { NZ Euro/Pākehā } \\
3.63\end{array}$ & $\begin{array}{l}\text { Other ethnic groups } \\
.834 \\
\text { NZ Euro/Pākehā } \\
1.08\end{array}$ & $\begin{array}{l}\text { Small } \\
.045\end{array}$ \\
\hline - Kaupapa Māori & $(F(4,257)=6.074, \quad p<.001)$ & $\begin{array}{l}\text { Māori } \\
2.65 \\
\text { NZ Euro/Pākehā } \\
1.84\end{array}$ & $\begin{array}{l}\text { Māori } \\
1.508 \\
\text { NZ Euro/Pākehā } \\
1.01\end{array}$ & $\begin{array}{l}\text { Medium } \\
.086\end{array}$ \\
\hline - Pasifika-based & $(F(4,253)=11.384, p<.001)$ & $\begin{array}{l}\text { Pacific peoples } \\
2.74 \\
\text { Māori } \\
1.33 \\
\text { NZ Euro/Pākehā } \\
1.41\end{array}$ & $\begin{array}{l}\text { Pacific peoples } \\
1.522 \\
\text { Māori } \\
.689 \\
\text { NZ Euro/Pākehā } \\
.742\end{array}$ & $\begin{array}{l}\text { Large } \\
.153\end{array}$ \\
\hline - Karakia & $(F(4,258)=9.492, p<.001)$ & $\begin{array}{l}\text { Māori } \\
2 \\
\text { NZ Euro/Pākehā } \\
1.2 \\
\text { Indian } \\
1.08 \\
\text { Other } \\
1.23\end{array}$ & $\begin{array}{l}\text { Māori } \\
1.471 \\
\text { NZ Euro/Pākehā } \\
.708 \\
\text { Indian } \\
.289 \\
\text { Other } \\
.77\end{array}$ & $\begin{array}{l}\text { Medium } \\
.128\end{array}$ \\
\hline
\end{tabular}




\section{ORIGINAL ARTICLE}

\section{QUANTITATIVE RESEARCH}

\begin{tabular}{|c|c|c|c|c|}
\hline Variables & ANOVA & Mean Differences $p<.05$ & SD & $\begin{array}{l}\text { Effect size } \\
\text { Eta squared }\end{array}$ \\
\hline $\begin{array}{l}\text { Experience in social work } \\
\text { - Internal supervision }\end{array}$ & $(F(6,242)=3.472, p<.001)$ & $\begin{array}{l}1-5 \text { years } \\
4.36 \\
16-20 \text { years } \\
3.32 \\
26-30 \text { years } \\
2.96\end{array}$ & $\begin{array}{l}1-5 \text { years } \\
.78 \\
16-20 \text { years } \\
1.572 \\
26-30 \text { years } \\
1.644\end{array}$ & $\begin{array}{l}\text { Medium } \\
.079\end{array}$ \\
\hline $\begin{array}{l}\text { My supervisor has more } \\
\text { expertise in practice } \\
\text { than me }\end{array}$ & $(F(6,266)=7.951, p<.001)$ & $\begin{array}{l}1-5 \text { years } \\
4.58 \\
11-15 \text { years } \\
3.69 \\
16-20 \text { years } \\
3.32 \\
21-25 \text { years } \\
3.26 \\
26-30 \text { years } \\
2.94 \\
>31 \text { years } \\
3.06\end{array}$ & $\begin{array}{l}1-5 \text { years } \\
.72 \\
11-15 \text { years } \\
1.385 \\
16-20 \text { years } \\
1.427 \\
21-25 \text { years } \\
1.389 \\
26-30 \text { years } \\
1.216 \\
>31 \text { years } \\
1.589\end{array}$ & $\begin{array}{l}\text { Large } \\
.152\end{array}$ \\
\hline $\begin{array}{l}\text { My supervisor has more } \\
\text { expertise in supervision } \\
\text { than me }\end{array}$ & $(F(6,265)=6.912, p<.001)$ & $\begin{array}{l}1-5 \text { years } \\
4.65 \\
6-10 \text { years } \\
4.3 \\
11-15 \text { years } \\
3.89 \\
16-20 \text { years } \\
3.26 \\
21-25 \text { years } \\
3.66 \\
26-30 \text { years } \\
3.25 \\
>31 \text { years } \\
3.17\end{array}$ & $\begin{array}{l}1-5 \text { years } \\
.839 \\
6-10 \text { years } \\
1.01 \\
11-15 \text { years } \\
1.17 \\
16-20 \text { years } \\
1.399 \\
21-25 \text { years } \\
1.438 \\
26-30 \text { years } \\
1.437 \\
>31 \text { years } \\
1.543\end{array}$ & $\begin{array}{l}\text { Medium } \\
.135\end{array}$ \\
\hline - Prioritisation of items & $(F(6,262)=3.222, p=.005)$ & $\begin{array}{l}6-10 \text { years } \\
3.71 \\
16-20 \text { years } \\
2.79\end{array}$ & $\begin{array}{l}6-10 \text { years } \\
1.155 \\
16-20 \text { years } \\
1.264\end{array}$ & $\begin{array}{l}\text { Medium } \\
.069\end{array}$ \\
\hline $\begin{array}{l}\text { Recognised qualification } \\
\text { - Managerial/ } \\
\text { administrative } \\
\text { supervision }\end{array}$ & $(F(5,226)=3.051, p<.01)$ & $\begin{array}{l}\text { Section } 13 \\
4.57 \\
\text { Diploma } \\
2.9 \\
\text { Bachelors } \\
2.64 \\
\text { PG Diploma } \\
3.1 \\
\text { Masters } \\
2.57\end{array}$ & $\begin{array}{l}\text { Section } 13 \\
.787 \\
\text { Diploma } \\
1.524 \\
\text { Bachelors } \\
1.502 \\
\text { PG Diploma } \\
1.729 \\
\text { Masters } \\
1.417\end{array}$ & $\begin{array}{l}\text { Small } \\
.049\end{array}$ \\
\hline
\end{tabular}




\begin{tabular}{|c|c|c|c|c|}
\hline Shared Agenda & $(F(5,269)=2.447, p=.034)$ & $\begin{array}{l}\text { Section } 13 \\
4.86 \\
\text { Diploma } \\
3.54 \\
\text { Bachelors } \\
3.83 \\
\text { PG Diploma } \\
3.83 \\
\text { Masters } \\
3.69\end{array}$ & $\begin{array}{l}\text { Section } 13 \\
.378 \\
\text { Diploma } \\
1.205 \\
\text { Bachelors } \\
.941 \\
\text { PG Diploma } \\
.923 \\
\text { Masters } \\
1.122\end{array}$ & $\begin{array}{l}\text { Small } \\
.043\end{array}$ \\
\hline Variables & ANOVA & Mean Differences $p<.05$ & SD & $\begin{array}{l}\text { Effect size } \\
\text { Eta squared }\end{array}$ \\
\hline $\begin{array}{l}\text { Sexual Orientation } \\
\text { - Checking in concerning } \\
\text { work plans and activity } \\
\text { - Performance } \\
\text { management }\end{array}$ & $\begin{array}{l}(F(2,244)=4.200, p=.016) \\
(F(2,247)=3.854, p=.022)\end{array}$ & $\begin{array}{l}\text { Heterosexual } \\
3.76 \\
\text { Same-sex } \\
3.08 \\
\\
\text { Bisexual } \\
3.75 \\
\text { Same-sex } \\
2.44 \\
\text { Heterosexual } \\
2.74\end{array}$ & $\begin{array}{l}\text { Heterosexual } \\
1.1 \\
\text { Same-sex } \\
1.139 \\
\\
\text { Bisexual } \\
.886 \\
\text { Same-sex } \\
1.193 \\
\text { Heterosexual } \\
1.167\end{array}$ & $\begin{array}{l}\text { Small } \\
.033 \\
\\
\text { Small } \\
.03\end{array}$ \\
\hline $\begin{array}{l}\text { Type of Registration } \\
\text { - I have a choice of } \\
\text { supervisor }\end{array}$ & $(F(2,272)=4.058, p=.018)$ & $\begin{array}{l}\text { Full } \\
3.09 \\
\text { Provisional } \\
1.91 \\
\text { Temporary } \\
1\end{array}$ & $\begin{array}{l}\text { Full } \\
1.711 \\
\text { Provisional } \\
.944 \\
\text { Temporary } \\
0\end{array}$ & $\begin{array}{l}\text { Small } \\
.029\end{array}$ \\
\hline $\begin{array}{l}\text { - My supervisor has more } \\
\text { expertise in supervision } \\
\text { than me }\end{array}$ & $(F(2,271)=3.546, p=.03)$ & $\begin{array}{l}\text { Provisional } \\
4.82 \\
\text { Full } \\
3.73\end{array}$ & $\begin{array}{l}\text { Provisional } \\
.405 \\
\text { Full } \\
1.36\end{array}$ & $\begin{array}{l}\text { Small } \\
.026\end{array}$ \\
\hline $\begin{array}{l}\text { Gender } \\
\text { - Individual supervision }\end{array}$ & $(F(3,239)=3.918, p<.01)$ & $\begin{array}{l}\text { Female } \\
4.15 \\
\text { Male } \\
3.4\end{array}$ & $\begin{array}{l}\text { Female } \\
1.189 \\
\text { Male } \\
1.397\end{array}$ & $\begin{array}{l}\text { Small } \\
.047\end{array}$ \\
\hline
\end{tabular}


The mean differences in regard to experience were, for the most part, expected and also highlight the need for further research regarding how supervision changes relative to a social workers' years of practice experience. Likewise, the differences concerning recognised qualification, sexual orientation, type of registration and gender, whilst small in effect, nonetheless identify key areas for further research regarding social work supervision in Aotearoa New Zealand and internationally. It is noted that previous studies were undertaken internationally in the 1980s and 1990s concerning gender within social work supervision (Chernesky, 1986; Hipp \& Munson, 1995; Matheson, 1999). Since then the construction of gender has evolved over the past 20 years and further research would be timely.

\section{Conclusion}

This article has presented some initial findings of a national survey of registered social workers in Aotearoa New Zealand with the aim of establishing a baseline in regard to their supervision and to compare and contrast their supervision with SWRB policy and guidelines (SWRB, 2015a, 2016). The results reveal that, overall, most registered social workers' supervision is in accordance with the Board's expectations and code. Registered social workers are also, on average, mostly satisfied and evaluate their supervision as very good. That said, there needs to be further work undertaken to ensure all registered social workers access appropriate professional supervision. This means improving the situation for those who are dissatisfied and experience poor supervision, so that they have better supervision. The SWRB also needs to ensure that all registered social workers have monthly supervision and have a written agreement or contract in place.

The findings and discussion have also raised questions concerning the cultural responsiveness of supervision to the cultural worldview of supervisees and clients, as well as the need to decolonise supervision and put culture at the forefront not as an add-on (Ruwhiu, 2019; Walsh-Tapiata \& Webster, 2004). Finally, the study has raised a number of further research areas regarding how diversity and differences are experienced among registered social workers in supervision. It is hoped that the ideas for further research exploring social differences such as gender, culture, sexual orientation, experience, qualifications, and registration status will be followed up both in Aotearoa New Zealand and internationally.

\section{References}

Autagavaia, M. (2001). A Tagata Pasifika supervision process: Authenticating difference. In L. Beddoe \& J. Worrall (Eds.), Supervision conference 7-8 July 2000 From rhetoric to reality. Keynote address and selected papers (pp. 45-53). Auckland, NZ: Auckland College of Education.

Caspi, J., \& Reid, W. (2002). Educational supervision in social work: A task-centred model for field instruction and staff development. New York, NY: Columbia University Press.

Chernesky, R. (1986). A new model of supervision. In N. Van Den Bergh \& L. Cooper (Eds.), Feminist visions for social work (pp. 128-148). Silver Spring, MD: NASW Press.

Dalhousie, S. (2010). Editorial. Aotearoa New Zealand Social Work, 22(4), 1-4. doi:http://dx.doi.org/10.11157/anzswjvol22iss 4 id 173

Davys, A., \& Beddoe, L. (2010). Best practice in professional supervision: A guide for the helping professions. London, UK: Jessica Kingsley Publishers.

Davys, A. M., May, J., Burns, B., \& O’Connell, M. (2017). Evaluating social work supervision. Aotearoa New Zealand Social Work, 29(3), 108-121. doi:10.11157/anzswj-vol29iss3id314

De Vaus, D. (2014). Surveys in social research (6th ed.). Crows Nest, NSW: Allen and Unwin.

Eruera, M. (2012). He kōrari, he kete, he kōrero. Aotearoa New Zealand Social Work, 24(3-4), 12-19. doi:http://dx.doi.org/10.11157/anzswj-vol24iss3-4id103.

Field, A. (2013). Discovering statistics using IBM SPSS statistics (4th ed.). Los Angeles, CA: Sage Publications.

Hair, H. J., \& O'Donoghue, K. (2009). Culturally relevant, socially just social work supervision: Becoming visible through a social constructionist lens. Journal of Ethnic and Cultural Diversity in Social Work, 18, (1/2) 70-88. doi:10.1080/15313200902874979

Helms, J., Henze, K., Sass, L., \& Mifsud, V. (2006). Treating Cronbach's alpha reliability coefficients as data in counseling research. The Counseling Psychologist, 34(5), 630-660.

Henrickson, M., Neville, S., Jordan, C., \& Donaghey, S. (2007). Lavender islands. Journal of Homosexuality, 53(4), 223-248. doi:10.1080/00918360802103514 
Hipp, J., \& Munson, C. (1995). The partnership model: A feminist supervision/consultation perspective. The Clinical Supervisor, 13(1), 23-38.

Kadushin, A. (1974). Supervisor-supervisee: A survey. Social Work, 19(3), 288-297. doi:10.1093/sw/19.3.288

Kadushin, A. (1993). Social work supervision: An updated survey. The Clinical Supervisor, 10(2), 9-27. doi:10.1300/J001v10n02_02

Kadushin, A., \& Harkness, D. (2014). Supervision in social work (5th ed.). New York, NY: Columbia University Press [Kindle DX version]. Retrieved from http://www.amazon.com

Matheson, J. (1999). The process of social work supervision: Women's perspectives. (Unpublished doctoral dissertation). University of Calgary, Alberta, Ann Arbor, MI: University Microfilms International.

O'Donoghue, K. (2013). Editorial: The Social Workers Registration Act (2003)-10 years on. Aotearoa New Zealand Social Work Review, 25(3), 1-2.

O'Donoghue, K. (2008). Towards improving social work supervision in Aotearoa New Zealand. Aotearoa New Zealand Social Work Review, 20(1), 10-21.

O'Donoghue, K. (2010). Towards the construction of social work supervision in Aotearoa New Zealand: A study of the perspectives of social work practitioners and supervisors (Unpublished doctoral thesis). Palmerston North: Massey University. http://mro.massey.ac.nz/ handle/10179/1535

O'Donoghue, K., Munford, R., \& Trlin, A. (2005). Mapping the territory: Supervision within the association. Social Work Review, 17(4), 46-64.

O'Donoghue, K., Munford, R., \& Trlin, A. (2006). What's best about social work supervision according to association members. Social Work Review, 18(3), 79-91.

O'Donoghue, K., \& Tsui, M. S. (2012). Towards a professional supervision culture: The development of social work supervision in Aotearoa New Zealand. International Social Work, 55(1), 5-28. doi: 10.1177/0020872810396109

O'Donoghue, K., \& Tsui, M. S. (2015). Social work supervision research (1970-2010): The way we were and the way ahead. The British Journal of Social Work, 45(2), 616-633. doi:10.1093/bjsw/bct115

Pallant, J. (2013). SPSS survival guide (5th ed.). Crows Nest, NSW: Allen \& Unwin.

Ruwhiu, P. (2019). Emancipate yourself from mental slavery, none but ourselves can free our minds: Wetekia te mau here o te hinengaro, ma t tou an e whakaora, e whakaw tea te hinengaro (Unpublished doctoral thesis). Massey University: Palmerston North.

Schmitt, N. (1996). Uses and abuses of coefficient alpha. Psychological Assessment, 8(4), 350-353.

Simmons, H. (2001). Let the symbol speak: Developing a feminist spiral model of supervision. In L. Beddoe \& J. Worrall (Eds.), Supervision conference from rhetoric to reality keynote address and selected papers (pp. 177-185). Auckland, NZ: Auckland College of Education.

Social Workers Registration Board. (2015a). Supervision expectations for registered social workers: Policy statement. Retrieved from http://swrb.govt.nz/download/ supervision-expectations-for-registered-social-workers/

Social Workers Registration Board. (2015b). Annual report presented to the House of Representatives pursuant to section 150 of the Crown Entities Act 2004, 2014-2015. Retrieved from http://swrb.govt.nz/download/swrbannual-report-2014-2015/

Social Workers Registration Board. (2016). Code of Conduct. Retrieved from http://swrb.govt.nz/download/swrb-codeof-conduct-march-2016/

Statistics New Zealand. (2017a). 2013 Census information by variable. Retrieved from http://www.stats.govt.nz/ Census/2013-census/info-about-2013-census-data/ information-by-variable/sex.aspx

Statistics New Zealand. (2017b). Preliminary view of 2018 census content: For public engagement and consultation. Retrieved from http://www.stats.govt.nz/Census/ 2018-census/prelim-content/proposed-topics.aspx

Su'a-Hawkins, A., \& Mafile'o, T. (2004). What is cultural supervision? Social Work Now, 29, 10-16.

Thomas, C., \& Davis, S. (2005). Bicultural strengths-based supervision. In M. Nash, R. Munford, \& K. O'Donoghue (Eds.), Social work theories in action (pp. 189-204). London, UK: Jessica Kingsley Publishers.

Thomas, F. (2013). Solution focused supervision-A resource-oriented approach to developing clinical expertise. New York, NY: Springer.

Walsh-Tapiata, W., \& Webster, J. (2004). Do you have a supervision plan? Te Komako VII, Social Work Review, 16(2), 15-19.

Watkins, C. E. (2011). Psychotherapy supervision since 1909: Some friendly observations about its first century. Journal of Contemporary Psychotherapy 41(1), 57-67. 